\title{
Influence of low- and high-protein diets on glucose homeostasis in the rat
}

\author{
BY W. OKITOLONDA, S. M. BRICHARD, A. M. POTTIER \\ AND J. C. HENQUIN* \\ Unité de Diabétologie et Nutrition, University of Louvain Faculty of Medicine, \\ UCL 54.74, B-1200 Brussels, Belgium
}

(Received 6 November 1987 - Accepted 11 July 1988)

\begin{abstract}
1. The influence of the protein content of the diet on glucose homeostasis was studied in the rat. Rats of $28 \mathrm{~d}$ of age received ad lib. a control diet containing $(\mathrm{g} / \mathrm{kg}) 150$ protein $(\mathrm{P} 15)$, or a diet containing 50 protein (P5) or 450 protein (P45). Since P5 rats spontaneously reduced their food intake, a fourth group of rats (P25) received the same amount of energy as P5 rats and the same amount of protein as P15 rats.

2. After 12-13 weeks on these diets, plasma glucose and insulin levels were similar in fed P45, P25 and control P15 rats, but were lower in P5 rats. In fasted animals, plasma glucose and insulin levels were also decreased in P5 rats, whereas plasma glucose levels were increased in both P45 and P25 animals.

3. During an oral glucose tolerance test, the glucose rise was only slightly larger in P5 than in P15 rats in spite of a considerably smaller increase in insulin levels. P45 rats displayed a normal tolerance to glucose with a normal insulin response, whereas tolerance to glucose was slightly poorer in P25 rats in spite of a normal insulin response.

4. Pancreatic insulin stores were lower in P5 than in control P15 rats, not only because of the smaller size of their pancreas, but also because of a decrease in the insulin concentration in the gland. A much smaller decrease was also observed in P25 rats, whereas insulin reserves were not altered in P45 rats.

5. It is concluded that the changes in glucose homeostasis observed in protein-energy malnutrition (P5 rats) are due to protein deprivation rather than to energy deprivation. A high-protein diet has little influence on glucose homeostasis in the rat.
\end{abstract}

Protein malnutrition is known to alter glucose homeostasis in man and in several animal species (Heard, 1978; Becker, 1983). Recognition that diabetes sometimes presents particular clinical features in regions of endemic protein-energy malnutrition has even led to the hypothesis that undernutrition may play a causal role in the pathogenesis of one form of the disease (Rao, 1984; Mohan et al. 1985; Abu-Bakare et al. 1986).

Recent experimental studies, using rats fed on a low-protein diet, have characterized some of these abnormalities of glucose homeostasis, and have determined their evolution with time and partial reversal on refeeding a control diet (Dollet et al. 1985; Okitolonda et al. 1987; Swenne et al. 1987). A marked insensitivity of pancreatic B-cells to various secretagogues, and a high sensitivity of peripheral tissues to insulin appear to be two major characteristics of these rats, the co-existence of which may explain why the animals do not develop overt glucose intolerance. However, it is still unclear to what extent these changes must be ascribed to protein restriction or to energy restriction, since young rats receiving a low-protein diet spontaneously reduce their food intake. This was the question addressed in the present study, in which we also investigated the influence of a high-protein diet on glucose homeostasis.

\section{MATERIAL AND METHODS}

$$
\text { Diets }
$$

Four types of isoenergetic diet in powdered form were prepared by mixing in appropriate proportions a protein-free diet and a diet containing $500 \mathrm{~g}$ protein $/ \mathrm{kg}$ (Usine

* For reprints. 
Table 1. Composition of the diets $(\mathrm{g} / \mathrm{kg})$

\begin{tabular}{lrrrr}
\hline Diet $\ldots$ & P15 & P5 & P45 & P25 \\
\hline Casein & 150 & 50 & 450 & $250 \ddagger$ \\
Starch & 412 & 487 & 187 & $337 \ddagger$ \\
Glucose & 138 & 163 & 63 & $113 \ddagger$ \\
Cellulose & 170 & 170 & 170 & 170 \\
Maize oil & 50 & 50 & 50 & 50 \\
Vitamin mixture* & 10 & 10 & 10 & 10 \\
Mineral mixture $\dagger$ & 70 & 70 & 70 & 70 \\
\hline
\end{tabular}

* Contained $(\mathrm{g} / \mathrm{kg}$ vitamin mixture): retinol $0 \cdot 6$, cholecalciferol $0 \cdot 006$, thiamin $2 \cdot 0$, riboflavin $1 \cdot 5$, pantothenic acid $7 \cdot 0$, pyridoxine $1 \cdot 0, \psi$-inositol $15 \cdot 0$, cyanocobalamin 0.005 , ascorbic acid 80 , tocopherol $17 \cdot 0$, menadione $4 \cdot 0$, nicotinic acid $10 \cdot 0$, choline 136, pteroylmonoglutamic acid $0.5, p$-aminobenzoic acid 5.0, biotin 0.03 .

$\dagger$ Contained (g/kg mineral mixture): $\mathrm{CaHPO}_{4} 430, \mathrm{KCl} 100, \mathrm{NaCl} 100, \mathrm{MgO} \mathrm{10} \cdot 5, \mathrm{MgSO}_{4} 50, \mathrm{Fe}_{2} \mathrm{O}_{3} 3$, $\mathrm{Fe}_{2} \mathrm{SO}_{4} .7 \mathrm{H}_{2} \mathrm{O} 5, \mathrm{MnSO}_{4} . \mathrm{H}_{2} \mathrm{O} 2 \cdot 45, \mathrm{CuSO}_{4} .5 \mathrm{H}_{2} \mathrm{O} 0 \cdot 5, \mathrm{ZnSO}_{4} .7 \mathrm{H}_{2} \mathrm{O} 2 \cdot 0, \mathrm{CoSO}_{4} .7 \mathrm{H}_{2} \mathrm{O} 0 \cdot 004, \mathrm{KIO}_{3} 0.008$.

$\ddagger$ Approximate values.

d'Alimentation Rationnelle, Epinay/Orge, France). The final composition of these diets is given in Table 1. The dietary treatment groups were: control diet ( $150 \mathrm{~g}$ protein $/ \mathrm{kg}, \mathrm{P} 15)$; the low-protein diet ( $50 \mathrm{~g}$ protein $/ \mathrm{kg}, \mathrm{P} 5$ ); and the high-protein diet $(450 \mathrm{~g}$ protein $/ \mathrm{kg}$, P45) fed ad lib. The fourth diet, containing approximately $250 \mathrm{~g}$ protein $/ \mathrm{kg}$ (P25), was given in restricted amounts (see below).

\section{Animals}

The animals used were Wistar male rats. They were weaned at $21 \mathrm{~d}$ and received diet P15 for 1 week. They were then divided into four experimental groups of seven rats, matched for initial body-weight, and housed in a temperature- and light-controlled room $\left(22^{\circ}, 12 \mathrm{~h}\right.$ light $-12 \mathrm{~h}$ dark cycle with lights on at 07.00 hours). Between the ages of 4 and 8 weeks the animals were housed in individual metabolism cages permitting daily measurement of food and water intake, and collection of urine and faeces. Between the ages of 8 and 17 weeks, they were housed in individual ordinary cages and food intake was measured every 3 rd day. Food was provided ad lib. to P15, P5 and P45 rats, whereas P25 rats received the same amount of food as that consumed by P5 rats. The protein content of that food $(250-270 \mathrm{~g} / \mathrm{kg})$ was calculated to provide these rats with the same amount of protein as that consumed by P15 rats. The amount of food and its protein content were adjusted every 3rd day. The P25 rats were thus pair-fed for energy with P5 rats, and pair-fed for protein with control P15 rats. However, they were fed once daily, at 17.00 hours, and it should be noted that these hungry animals ate their whole ration in less than $3 \mathrm{~h}$.

\section{Sampling procedures and glucose-tolerance test}

On several occasions, blood $(250 \mu \mathrm{l})$ was taken from fed animals (between 08.00 and 09.00 hours), by cutting the tip of the tail. At the age of 16 weeks, all rats underwent an oral glucose-tolerance test (OGTT). The test started between 08.00 and 09.00 hours. On the day before the test, P25 rats (usually fed at 17.00 hours) received their normal ration at 16.00 hours, but the remaining food was removed at 17.00 hours. Food was removed from the other rats at the same time. For the OGTT, glucose $(400 \mathrm{~g} / 1$ water) was introduced directly into the stomach through a fine gastric catheter, at a dose of $2 \mathrm{~g} / \mathrm{kg}$ body-weight. All rats were finally killed by decapitation (in the fed state) at the age of 17 weeks. Their pancreases were resected, weighed and quickly frozen in liquid nitrogen. 


\section{Analytical procedures}

Plasma glucose was measured on the day of the experiment by a glucose oxidase $(E C$ 1.1.3.4) method (Glucose Analyser; Beckman). The samples were then kept frozen at $-20^{\circ}$ until insulin measurement by a double-antibody radioimmunoassay, using rat insulin as a standard (Novo Research Institute, Bagsvaerd, Denmark). Pancreatic insulin was extracted after homogenization and sonication of the tissue in acidified ethanol.

\section{Presentation of results}

Results are presented as means with their standard errors. Comparisons between groups of rats receiving different types of diet were carried out by analysis of variance, and where this showed a treatment effect groups were compared by the test of Newman-Keuls for multiple comparisons (Sokal \& Rohlf, 1969). Differences were considered statistically significant at $P<0.05$.

\section{RESULTS}

Influence of dietary protein level on body-weight gain and on food intake

At the age of $28 \mathrm{~d}$, before being given the different types of diet, the rats had an average body-weight of 74 (sE 1) g. As shown in Fig. 1, body-weight gain was similar in P15 and P45 rats, very low in P5 rats and intermediate in P25 rats. After 13 weeks on the respective diets (17-week-old rats), the mean (with SE) body-weights (g) of P15, P5, P45 and P25 rats were respectively (with statistical significance of difference between means for dietary group and that of P15 (control)) 335 (SE 6), 143 (SE 4) $(P<0.001$ ), 352 (SE 6) (not significant) and 239 (SE 5) $(P<0.001)$. The difference between P5 and P25 rats was also significant $(P<0.001)$.

Average body-weight gain, food intake and water intake for the 2 nd -4 th weeks on the diets are presented in Table 2. P5 rats consumed about $45 \%$ less energy and $80 \%$ less protein than control P15 rats, and body-weight gain was approximately $80 \%$ lower. Water intake and urine volume were also markedly decreased. P45 rats consumed the same amount of food as control P15 rats, and body-weight gain was also similar in spite of a three-fold greater protein intake. Daily water intake and urine volume were both $6-7 \mathrm{ml}$ higher than those of P15 rats. This is likely to be due to the need to eliminate higher amounts of nigrogen. P25 rats were given the same amount of energy as P5 rats, and the same amount of protein as P15 rats. Body-weight gain was intermediate, and significantly different from $\mathrm{P} 15$ rats $(P<0.01)$ and from $\mathrm{P5}$ rats $(P<0.01)$. Although the water intake was significantly lower $(P<0.01)$ than for P15 rats (controls), urine volume was similar. Gross energy efficiency (body-weight gain/MJ) was significantly lower $(P<0.01)$ for P5 rats and higher for $\mathrm{P} 45$ and $\mathrm{P} 25$ rats $(P<0.05)$ than for controls. On the other hand, the protein efficiency was increased in P5 rats $(P<0.01)$ and reduced in P45 and P25 rats $(P<0.01)$. The differences between P5 and P25 rats, which had the same energy intake, were also statistically significant $(P<0 \cdot 001)$.

\section{Influence of dietary protein level on glucose homeostasis}

In fed P5 rats, plasma glucose levels were similar to controls after 4 weeks but lower $(P<0.05)$ after 13 weeks (Table 3). Plasma insulin levels and the insulin: glucose values were consistently lower $(P<0.01)$ compared with control P15 rats (Table 3$)$. In fasted P5 rats, plasma glucose and insulin levels and the insulin:glucose values were decreased. In contrast, in rats receiving a high-protein diet (P45), the only significant change was an increase in fasted plasma glucose levels. In fed P25 rats, plasma glucose and insulin levels were decreased after 4 weeks but not after 13 weeks. On the other hand, fasted plasma 


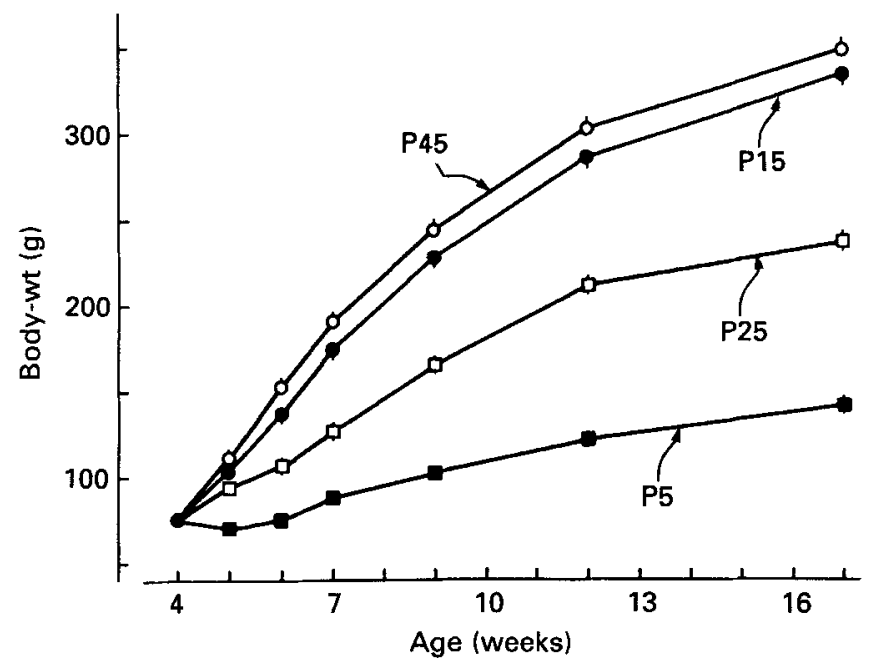

Fig. 1. Body-weights of rats receiving diets containing (O) 150 (P15), (U) 50 (P5) and (O) 450 (P45) g protein $/ \mathrm{kg}$ and fed ad lib. from the age of 4 weeks onwards. ( $\square$ ) Rats receiving the same amount of energy as P5 rats and the same amount of protein as P15 rats (P25). Values are means with their standard errors represented by vertical bars for seven rats in each group.

Table 2. Body-weight (BW) gain, food and water intake, and gross efficiency of energy and protein utilization in rats receiving diets with different protein contents $\dagger$

(Mean values with their standard errors for seven rats. Diets containing 150,50 and $450 \mathrm{~g}$ protein $/ \mathrm{kg}$ (P15, P5 and P45 respectively) were provided ad lib. A fourth group of rats received the same amount of energy as P5 rats and the same amount of protein as P15 rats (P25). Daily measurements made during the 2 nd, 3 rd and 4 th week on the test diets (35 to 56-day-old rats) were averaged for each animal)

\begin{tabular}{|c|c|c|c|c|c|c|c|c|}
\hline \multirow[t]{2}{*}{ Dietary treatment group ... } & \multicolumn{2}{|c|}{ P15 } & \multicolumn{2}{|c|}{ P5 } & \multicolumn{2}{|c|}{ P45 } & \multicolumn{2}{|c|}{$\mathrm{P} 25$} \\
\hline & Mean & $\mathrm{SE}$ & Mean & $\mathrm{SE}$ & Mean & $\mathrm{SE}$ & Mean & $\mathrm{SE}$ \\
\hline $\mathrm{BW}$ gain $(\mathrm{g} / \mathrm{d})$ & 4.9 & $0 \cdot 1$ & $1 \cdot 1^{* *}$ & $0 \cdot 1$ & $5 \cdot 0$ & $0 \cdot 2$ & $2 \cdot 8^{* *}$ & $0 \cdot 1$ \\
\hline Food intake $(\mathrm{MJ} / \mathrm{d})$ & $0 \cdot 26$ & 0.01 & $0 \cdot 14^{* *}$ & 0.01 & $0 \cdot 24$ & 0.01 & $0 \cdot 14^{* *}$ & \\
\hline Protein intake $(\mathrm{g} / \mathrm{d})$ & $2 \cdot 8$ & 0.06 & $0.51 * *$ & 0.03 & $7 \cdot 9 * *$ & 0.22 & $2 \cdot 8$ & \\
\hline Water intake $(\mathrm{ml} / \mathrm{d})$ & $33 \cdot 9$ & $2 \cdot 4$ & $14 * *$ & 1.3 & $40 \cdot 5^{* *}$ & $1 \cdot 4$ & $26 \cdot 1^{* *}$ & $1 \cdot 2$ \\
\hline Urine volume $(\mathrm{ml} / \mathrm{d})$ & $18 \cdot 6$ & $2 \cdot 3$ & $5 \cdot 2 * *$ & 0.8 & $25 \cdot 8^{* *}$ & $1 \cdot 1$ & $18 \cdot 0$ & $1 \cdot 0$ \\
\hline $\begin{array}{l}\text { Energy conversion efficiency } \\
\text { (g BW gain } / \mathrm{MJ} \text { ) }\end{array}$ & $18 \cdot 9$ & 0.2 & $7.9 * *$ & $0 \cdot 7$ & $20 \cdot 6^{*}$ & $0 \cdot 2$ & $20 \cdot 6^{*}$ & 0.5 \\
\hline $\begin{array}{l}\text { Protein conversion efficiency } \\
\text { (g BW gain/g protein) }\end{array}$ & $1 \cdot 74$ & 0.03 & $2 \cdot 15^{* *}$ & $0 \cdot 16$ & $0 \cdot 63^{* *}$ & $0-01$ & $1.01^{* *}$ & 0.03 \\
\hline
\end{tabular}

Mean values were significantly different from those for control $P 15$ rats: ${ }^{*} P<0 \cdot 05,{ }^{* *} P<0 \cdot 01$.

$\dagger$ For details, see Table I and p. 510.

glucose and insulin levels were higher than those in control P15 rats. These differences may be partly due to the particular pattern of feeding of these rats, which received only one meal at $\mathbf{1 7 . 0 0}$ hours. They were 'less fed' than fed controls and 'less fasted' than fasted controls at the time of sampling. It is also noteworthy that, probably due to ageing of the animals, plasma insulin levels and the insulin:glucose values were higher after 13 weeks than after 4 weeks in all groups (Table 3 ).

Fig. 2 illustrates the changes in plasma glucose and insulin levels measured during an OGTT in the four groups of rats after 12 weeks on their respective diets. At all times of the test, except at 0 min (see Table 3), plasma glucose levels were similar for P5 and P15 rats. 
Table 3. Plasma glucose and plasma insulin levels in rats receiving diets with different protein contents $\dagger$

(Mean values with their standard errors for seven rats. Diets containing 150,50 and $450 \mathrm{~g}$ protein $/ \mathrm{kg}$ (P15, P5 and P45 respectively) were provided. A fourth group of rats received the same amount of energy as P5 rats and the same amount of protein as P15 rats (P25). After 4, 12 and 13 weeks on the different diets, the animals were 8,16 and 17 weeks of age respectively. For fed rats food was provided ad lib. until blood sampling, between 8 and $9 \mathrm{~h}$, except for P25 rats, which received their daily ration at 17.00 hours on the day before sampling. Sampling in fasted rats corresponded to time 0 of the oral glucose-tolerance test)

\begin{tabular}{|c|c|c|c|c|c|c|c|c|c|}
\hline \multicolumn{2}{|l|}{ Dietary treatment group ... } & \multicolumn{2}{|c|}{ PIs } & \multicolumn{2}{|c|}{ P5 } & \multicolumn{2}{|c|}{ P45 } & \multicolumn{2}{|c|}{$\mathbf{P} 25$} \\
\hline & diet (weeks) & Mean & $\overline{\mathrm{SE}}$ & Mean & $\mathrm{SE}$ & Mean & $\overline{\mathrm{SE}}$ & Mean & $\mathrm{SE}$ \\
\hline Fed rats & 4 & & & & & & & & \\
\hline Plasma glucose $(\mathrm{mM})$ & & $7 \cdot 45$ & $0 \cdot 18$ & 7.48 & 0.25 & 7.64 & 0.19 & $6 \cdot 61^{* *}$ & 0.15 \\
\hline Plasma insulin $(\mathrm{ng} / \mathrm{ml})$ & & $1 \cdot 31$ & 0.28 & $0 \cdot 34 * *$ & 0.05 & 1.49 & 0.17 & $0.84^{*}$ & 0.15 \\
\hline Insulin:glucose & & $0 \cdot 17$ & 0.03 & $0.05 * *$ & 0.01 & 0.20 & 0.02 & 0.13. & 0.02 \\
\hline Fed rats & 13 & & & & & & & & \\
\hline Plasma glucose (mM) & & 7.87 & $0 \cdot 37$ & $6.94^{*}$ & $0 \cdot 16$ & $7 \cdot 54$ & 0.14 & $7 \cdot 13$ & 0.22 \\
\hline Plasma insulin $(\mathrm{ng} / \mathrm{ml})$ & & 1.73 & $0 \cdot 16$ & $0 \cdot 61^{* *}$ & 0.06 & 1.97 & $0 \cdot 20$ & 1.97 & 0.35 \\
\hline Insulin: glucose & & 0.22 & 0.01 & $0.09 * *$ & 0.01 & 0.26 & 0.03 & 0.28 & 0.05 \\
\hline Fasted rats & 12 & & & & & & & & \\
\hline Plasma glucose (mм) & & $5 \cdot 54$ & $0 \cdot 22$ & $4 \cdot 05^{* *}$ & $0 \cdot 12$ & $6 \cdot 43^{* *}$ & $0 \cdot 12$ & $6 \cdot 46^{* *}$ & 0.22 \\
\hline Plasma insulin $(\mathrm{ng} / \mathrm{ml})$ & & 0.82 & 0.09 & $0 \cdot 35^{* *}$ & 0.05 & 0.94 & 0.18 & $1 \cdot 26^{*}$ & 0.08 \\
\hline Insulin: glucose & & 0.15 & 0.02 & $0.09^{*}$ & 0.01 & $0 \cdot 15$ & 0.03 & 0.20 & 0.01 \\
\hline
\end{tabular}

Mean values were significantly different from those for control P15 rats: ${ }^{*} P<0.05, * * P<0.01$.

$\dagger$ For details, see Table 1 and p. 510.

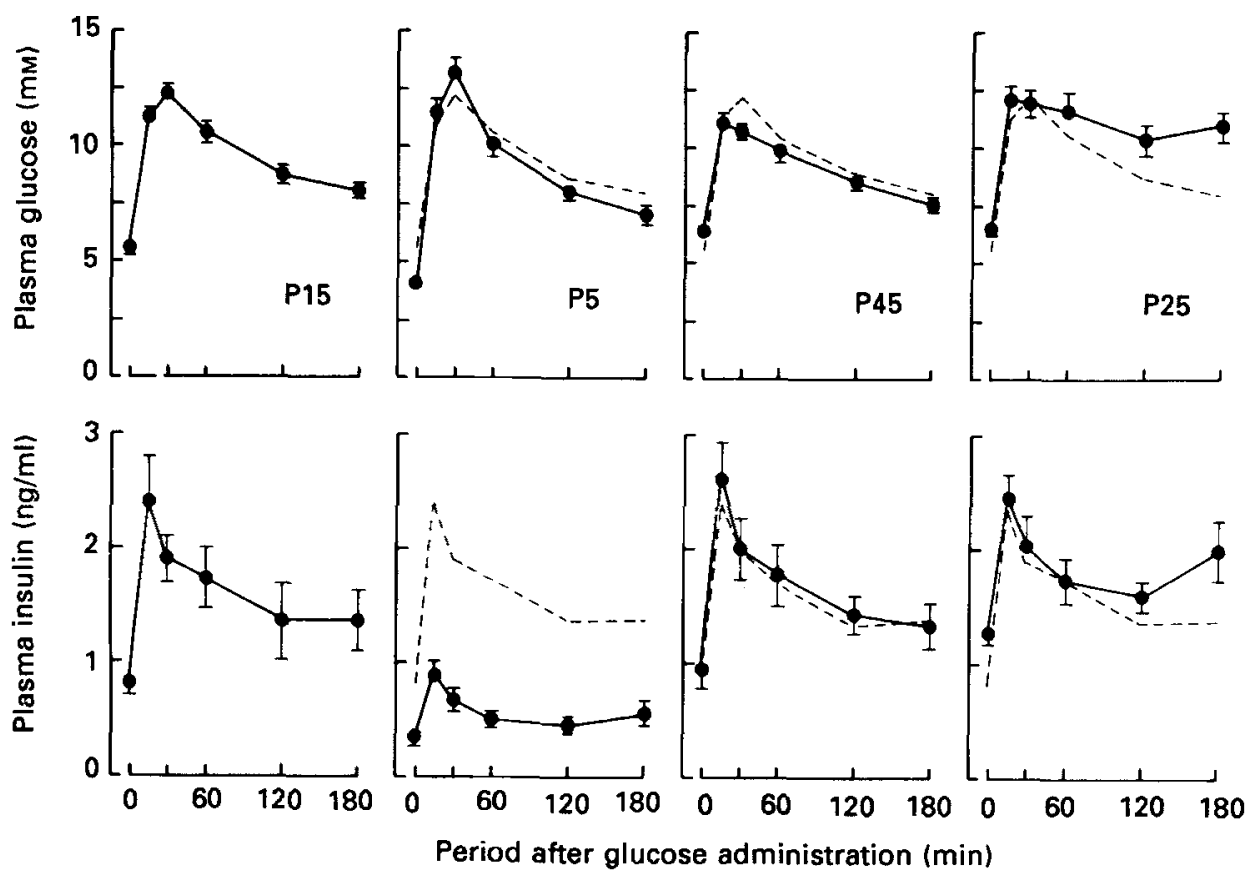

Fig. 2. Plasma glucose and insulin levels during an oral glucose tolerance test in rats receiving diets containing $150(\mathrm{P} 15), 50(\mathrm{P} 5)$ or $450(\mathrm{P} 45)$ g protein $/ \mathrm{kg}$, or receiving the same amount of energy as $\mathrm{P} 5$ rats and the same amount of protein as P15 rats (P25), for 12 weeks (16-week-old rats). (--) Results for control P15 rats. Values are means with their standard errors represented by vertical bars for seven rats in each group. 
Table 4. Pancreatic insulin reserves in rats receiving diets with different protein contents $\dagger$

(Mean values with their standard errors for seven rats. Diets containing 150,50 and $450 \mathrm{~g}$ protein $/ \mathrm{kg}$ (P15, P5 and P45 respectively) were provided. A fourth group of rats received the same amount of energy as P5 rats and the same amount of protein as P15 rats (P25). The rats were killed at the age of 17 weeks, i.e. after 13 weeks on the different diets)

\begin{tabular}{|c|c|c|c|c|c|c|c|c|}
\hline \multirow{2}{*}{$\begin{array}{c}\text { Dietary treatment } \\
\text { group ... }\end{array}$} & \multicolumn{2}{|c|}{ P15 } & \multicolumn{2}{|c|}{ P5 } & \multicolumn{2}{|c|}{ P45 } & \multicolumn{2}{|c|}{$\mathrm{P} 25$} \\
\hline & Mean & $\mathrm{SE}$ & Mean & SE & Mean & $\mathrm{SE}$ & Mean & $\mathrm{SE}$ \\
\hline \multicolumn{9}{|l|}{ Wt of pancreas } \\
\hline g & 0.88 & 0.02 & $0 \cdot 43 * *$ & 0.01 & $1.00^{* *}$ & 0.02 & $0 \cdot 80^{*}$ & 0.03 \\
\hline $\mathrm{g} / \mathrm{kg}$ body wt & 2.63 & 0.08 & $3 \cdot 00$ & $0 \cdot 10$ & $2 \cdot 86$ & 0.07 & $3 \cdot 34^{* *}$ & $0 \cdot 11$ \\
\hline \multicolumn{9}{|c|}{ Insulin concentration and content $(\mu \mathrm{g})$} \\
\hline /g pancreas & 218 & 11 & $117 * *$ & 6 & $182 *$ & 5 & $150^{* * *}$ & 9 \\
\hline /pancreas & I9I & 6 & $50^{* *}$ & 2 & 183 & 6 & $120^{* *}$ & 10 \\
\hline$/ \mathrm{kg}$ body-wt & 570 & 23 & $350^{* *}$ & 18 & 520 & 20 & 502 & 37 \\
\hline
\end{tabular}

Mean values were significantly different from those for control P15 rats: ${ }^{*} P<0.05,{ }^{* *} P<0.01$.

$\dagger$ For details, see Table $l$ and p. 510 .

However, the maximum increase (between 0 and $30 \mathrm{~min}$ ) was $36 \%$ greater in P5 rats (9.10 (SE 0.61) $\mathrm{mM}$ ) than in control P15 rats $(6.68$ (SE 0.14) $\mathrm{mm}$ ). In contrast, plasma insulin levels were very low before and during the OGTT in the P5 rats. The plasma glucose levels of P45 rats were similar to those of controls during the test. However, the initial value was higher (Table 3) and the maximum increase in plasma glucose was $31 \%$ lower (4.61 (SE 0.28) mM at $15 \mathrm{~min}$ ) than in P15 rats. Neither before nor during the OGTT was there any difference in plasma insulin levels between P45 and P15 rats. In P25 rats, plasma glucose levels were $(P<0.01)$ higher before and at 120 and $180 \mathrm{~min}$. Plasma insulin levels were also higher before $(P<0.05)$, but not during the OGTT (Fig. 2).

The influence of the diet on pancreatic insulin reserves is shown in Table 4. Relative to P15 controls, pancreas weight was lower in P5 $(P<0.01)$ and P25 rats $(P<0.05)$ and higher in $\mathrm{P} 45(P<0.01)$. When expressed relative to body-weight, the only significant effect was a $26 \%$ increase in the P25 group $(P<0.01)$. Pancreas insulin concentration was significantly reduced relative to controls in P5 and P25 rats $(P<0.01)$, and in P45 rats $(P<0.05)$. As a result of the combined effects of weight and concentration, the total insulin content in P5 rats was less than $30 \%$ of that in P15 rats $(P<0.01)$ and only $60 \%$ when related to body-weight $(P<0.01)$. Total insulin content in P25 rats was only $60 \%$ of the P15 value $(P<0.01)$, but there was no significant effect when related to body-weight.

\section{DISCUSSION}

The protein content of the diet markedly influenced spontaneous food consumption, bodyweight gain and gross efficiency of protein and energy utilization. Rats given a low-protein diet voluntarily reduced their food intake, as reported by others (Edozien, 1978; Phillips, 1981; Imai et al. 1986). The severely reduced rate of growth can thus be explained by a combined shortage of protein and energy. That both deficiencies play a role is demonstrated by the intermediate body-weight gain of double-pair-fed P25 rats, which received the same amount of energy as protein-deprived P5 rats, and the same amount of protein as control $\mathrm{P} 15$ rats. Energy consumption and body-weight gain of rats given a high-protein diet (P45) were similar to those of controls. A decrease in food intake with high-protein diets has sometimes been reported in other studies, but it was either transient (a few days) or 
significant only when the protein content exceeded $500-600 \mathrm{~g} / \mathrm{kg}$ diet (Edozien, 1978; Kettelhut et al. 1980; Usami et al. 1982; Imai et al. 1986). The efficiencies of energy and protein utilization for growth were very different in the four groups of rats, in agreement with previous reports (Edozien, 1978; Phillips, 1981; Mohan \& Narasinga Rao, 1983; Imai et al. 1986).

Fed and fasted protein-deprived P5 rats had slightly lower plasma glucose levels and markedly lower plasma insulin levels than controls. Though their insulin response was also strongly impaired during an OGTT, these animals did not display overt glucose intolerance : the increase in plasma glucose concentrations over basal levels was abnormal, but not the absolute glucose concentrations during the test. This extends previous reports (Younoszai \& Dixit, 1980; Levine et al. 1983; Okitolonda et al. 1987) that glucose tolerance is only marginally impaired in rats adapted to a low-protein diet for more than 10 weeks, in contrast to rats deprived of proteins for only 3-4 weeks (Weinkove et al. 1976; Bhutani et al. 1985). The low insulin:glucose values consistently measured in protein-deprived rats attest to their high sensitivity to insulin, a feature also previously characterized by a profound and long-lasting hypoglycaemia after injection of insulin (Weinkove et al. 1976; Okitolonda et al. 1987).

The P25 rats were pair-fed for energy with protein-deprived P5 rats and pair-fed for protein with control P15 rats. Despite their particular feeding pattern, these P25 rats can help to distinguish which of the abnormalities observed in P5 rats are due to protein or to energy deficiency. Isolated energy deprivation did not lead to the marked decrease in plasma insulin:glucose values nor to the impairment of B-cell responsiveness to glucose characteristic of P5 rats. Glucose tolerance of P25 rats was slightly lower than that in controls in spite of a normal rise in plasma insulin levels. Energy-restricted rats are thus not particularly sensitive to insulin, a conclusion also reached by others (Hell et al. 1980) after injection of insulin to food-restricted animals. These observations indicate, therefore, that the impairment of insulin release and the increase in insulin sensitivity observed in proteindeficient rats can be attributed to the shortage of proteins rather than to the decrease in energy consumption.

Microscopy studies of the pancreas of pigs (Heard et al. 1958) or rats (Weinkove et al. 1977) have shown that the islet volume is decreased after several weeks on a low-protein diet. These results were in contradiction with the reports (Weinkove et al. 1976; Levine et al. 1983; Bhutani et al. 1985) that pancreatic insulin concentration was unaffected or even increased in protein-deprived rats. However, the present and two recent studies (Dollet et al. 1985; Okitolonda et al. 1987) clearly show that pancreatic insulin stores are decreased in protein-deficient rats. Furthermore, our findings also establish that this decrease results mainly, though perhaps not exclusively, from the shortage of protein. Indeed, pancreatic insulin concentration was less affected by pure energy deprivation, and the insulin reserves of these P25 rats were not diminished when expressed relative to body-weight.

Comparison of our P45 rats with other studies of rats fed on high-protein diets is fraught with several difficulties: the protein content of the diet was higher in other studies $(550-700 \mathrm{~g} / \mathrm{kg}$ instead of $450 \mathrm{~g} / \mathrm{kg})$, and the diet was administered for shorter periods of time (1-6 weeks instead of 13 weeks), and generally to adult animals. However, there appears to be agreement between the present work and other studies on the following characteristics. Fed plasma glucose levels were not or only slightly increased, and fed plasma insulin levels are not modified in rats fed on high-protein diets (Blazquez \& Lopez Quijada, 1970; Eisenstein \& Strack, 1971; Peret et al. 1981; Eizirik \& Migliorini, 1984). On the other hand, fasting plasma glucose levels are higher than those in controls, not because of a greater decrease in plasma insulin but probably because of higher plasma glucagon levels and increased neoglucogenesis (Eisenstein \& Strack, 1976; Kettelhut et al. 
1980; Peret et al. 1981). Finally, our study shows that pancreatic insulin stores are not altered and that tolerance to oral glucose is normal in rats given a high-protein diet. The increase in plasma glucose levels was even lower than that in the controls, while the corresponding insulin response was similar.

The authors are grateful to Professor A. E. Lambert for support, and to N. Amat-Peiro and M. Detaille for editorial help. W.O. is supported by a fellowship of the AGCD, Brussels, and J.C.H. is 'Maître de Recherches' of the FNRS, Brussels.

\section{REFERENCES}

Abu-Bakare, A., Gill, G. V., Taylor, R. \& Alberti, K. G. M. M. (1986). Lancet i, 1135-1138.

Becker, D. J. (1983). Annual Reviews of Nutrition 3, 187-212.

Bhutani, V., Kumar, V. \& Misra, U. K. (1985). Nutrition Reports International 32, 1413-1420.

Blazquez, E. \& Lopez Quijada, C. (1970). Journal of Endocrinology 46, 445-451.

Dollet, J. M., Beck, B., Villaume, C., Max, J. P. \& Debry, G. (1985). Journal of Nutrition 115, 1581-1588.

Edozien, J. C. (1978). In Handbook Series in Nutrition and Food, sect. E, vol. 3, pp. 285-312 [M. Rechcigl, editor]. West Palm Beach: CRC Press.

Eisenstein, A. B. \& Strack, I. (1971). Diabetes 20, 577-585.

Eisenstein, A. B. \& Strack, I. (1976). Diabetes 25, 51-55.

Eizirik, D. L. \& Migliorini, R. H. (1984). Diabetes 33, 383-388.

Heard, C. R. C. (1978). World Review of Nutrition and Dietetics 30, 107-147.

Heard, C. R. C., Platt, B. S. \& Stewart, R. J. C. (1958). Proceedings of the Nutrition Society 17, 41-42.

Hell, N. S., Costa De Oliveira, L. B., Dolkinoff, M. S., Scivoletto, S. \& Timo-Iaria, C. (1980). Physiology and Behaviour 24, 473-477.

Imai, K., Ohnaka, M. \& Nijama, J. (1986). Journal of Nutritional Science and Vitaminology 32, 513-525.

Kettelhut, I. C., Foss, M. C. \& Migliorini, R. H. (1980). American Journal of Physiology 239, R437-R444.

Levine, L. S., Wright, P. G. \& Marcos, F. (1983). Acta Endocrinologica 102, 240-245.

Mohan, P. F. \& Narasinga Rao, B. S. (1983). Journal of Nutrition 113, 79-85.

Mohan, V., Ramachadran, A. \& Viswanathan, M. (1985). In The Diabetes Annual 1, pp. 82-92 [K. G. M. M. Alberti and L. P. Krall, editors]. Amsterdam: Elsevier.

Okitolonda, W., Brichard, S. M. \& Henquin, J. C. (1987). Diabetologia 30, 946-951.

Peret, J., Foustock, S., Chanez, M., Bois-Joyeux, B. \& Assan, R. (1981). Journal of Nutrition 111, $1173-1184$.

Phillips, L. S. (1981). In Endocrine Control of Growth, pp. 121-173 [W. H. Daughaday, editor]. New York: Elsevier.

Rao, R. H. (1984). Diabetes Care 6, 595-601.

Sokal, R. R. \& Rohlf, F. J. (1969). Biometry. The Principles and Practice of Statistics in Biological Research. San Francisco: W. H. Freeman and Co.

Swenne, I., Crace, C. J. \& Milner, D. G. (1987). Diabetes 36, 454-458.

Usami, M., Seino, S., Takemura, J., Nakahara, H., Ikeda, M. \& Imura, H. (1982). Journal of Nutrition 112 , $681-685$.

Weinkove, C., Weinkove, E. A. \& Pimstone, B. L. (1976). Clinical Science and Molecular Medicine 50, $153-163$

Weinkove, C., Weinkove, E. A., Timme, A. \& Pimstone, B. L. (1977) Archives of Pathology and Laboratory Medicine 101, 266-269.

Younoszai, R. \& Dixit, P. K. (1980). Proceedings of the Society for Experimental Biology and Medicine 164, $317-321$ 